\title{
PENERAPAN E-LEARNING MELALUI PEMBELAJARAN BERBASIS MASALAH UNTUK MENINGKATKAN KEMAMPUAN PEMECAHAN MASALAH MATEMATIS MAHASISWA
}

\author{
Glory Indira Diana Purba
}

Surel : glous_poerba @yahoo.com

\begin{abstract}
This study aims to determine whether the application of e-learning in problem-based learning can improve the problem solving abilities of FMIPA Unimed students. The approach used in this research is descriptive qualitative research by actively involving through e-learning the actors in the learning process, namely lecturers and students, as well as other related subjects. This study's design consists of three stages: (1) the development of learning tools and research instruments, (2) the testing of learning tools and research instruments, and (3) the implementation of experiments.
\end{abstract}

Keywords: Electronic Learning, Problem-Based Learning, Mathematica Problem Solving Ability

\begin{abstract}
ABSTRAK
Penelitian ini bertujuan untuk mengetahui apakah penerapan e-learning dalam pembelajaran berbasis masalah dapat meningkatkan kemampuan pemecahan masalah mahasiswa FMIPA Unimed. Pendekatan yang digunakan dalam penelitian ini adalah penelitian kualitatif deskriptif dengan melibatkan secara aktif melalui e-learning para pelaku dalam proses pembelajaran, yaitu dosen dan mahasiswa, serta mata pelajaran terkait lainnya. Rancangan penelitian ini terdiri dari tiga tahap: (1) pengembangan perangkat pembelajaran dan instrumen penelitian, (2) pengujian perangkat pembelajaran dan instrumen penelitian, dan (3) pelaksanaan eksperimen.
\end{abstract}

Kata Kunci: Pembelajaran Elektronik, Pembelajaran Berbasis Masalah, Kemampuan Pemecahan Masalah Matematis

\section{PENDAHULUAN}

Upaya meningkatkan kualitas pendidikan terus dilakukan baik secara konvensional maupun inovatif. Namun, mutu pendidikan terutama di perguruan tinggi belum menunjukkan hasil yang sebagaimana yang diharapkan kenyataan. Perlu dukungan dari berbagai pihak untuk meningkatkan kulitas pembelajaran, dimana salah satunya adalah metode/model pembelajaran yang tepat bagi mahasiswa. Menjadi seorang mahasiswa dituntut adanya peran aktif dalam proses pembelajaran. Artinya, sumber informasi mahasiswa tidak terbatas pada dosen dalam tatap muka, tetapi bisa dari berbagai sumber.

Penemuan teknologi-teknologi baru menjadi salah satu faktor penunjang bertambahnya kebutuhan baru dalam segala bidang, termasuk pada bidang pendidikan. Inovasiinovasi baru lahir seiring dengan berkembangnya teknologi dan kebutuhan pendidik dan terutama peserta didik. 
Sejak 16 Maret 2020 pemerintah memutuskan agar peserta didik belajar dari rumah. Dalam praktiknya, proses belajar mengajar di rumah, peserta didik dan guru dibantu dengan aplikasi belajar online. Dengan menyesuaikan sistem pembelajaran yang mengikuti perkembangan generasi saat ini, inovasi pembelajaran e-learning diharapkan dapat meningkatkan antusiasme dan pemahaman mahasiswa terutama pada kemampuan pemecahan masalah matematis. Oleh sebab itu e-learning yang dipakai adalah pembelajaran berbasis masalah. Penerapan metode ini berupaya membangun sistem pembelajaran yang membutuhkan siswa untuk belajar lebih berhasil dan memiliki keterampilan yang diperlukan di tempat kerja, serta mendorong siswa untuk kreatif dan bersemangat tentang kursus yang mereka ambil. Matematika sebagai salah satu sarana berpikir ilmiah sangat diperlukan untuk menumbuhkembangkan kemampuan berpikir logis, sistematis dan kritis. Demikian pula matematika merupakan pengetahuan dasar yang diperlukan untuk menunjang keberhasilan dalam menempuh pendidikan yang lebih tinggi, bahkan diperlukan oleh semua orang dalam kehidupan sehari-hari. Namun, mutu pendidikan belum menunjukkan hasil yang sebagaimana yang diharapkan. Kendala yang dihadapi dalam proses pembelajaran matematika yaitu kurang inovatifnya metode/model pembelajaran yang digunakan. Jika metode dan sumber belajar kurang menarik dan terkesan monoton maka akan menurunkan kualitas pembelajaran sehingga pemahaman mahasiswa tentang materi yang diajarkan menjadi terhambat.

Untuk meningkatkan kemampuan siswa, berbagai pendekatan pembelajaran dapat diterapkan. Siswa harus mampu memecahkan masalah sendiri dengan dukungan pendekatan pembelajaran. Di sini, instruktur harus dapat mengajari siswanya bagaimana mengembangkan keterampilan ini. Metode pembelajaran yang dipilih hendaknya disesuaikan dengan media atau sumber belajar lain yang dianggap relevan dalam menyampaikan informasi dan membimbing siswa untuk terlibat secara optimal, sehingga siswa dapat memperoleh pengalaman belajar dalam rangka mengembangkan kemampuan mental, intelektual, emosional, dan sosialnya. , serta keterampilan kognitif, afektif, dan psikomotorik.

Akibatnya, pembelajaran berbasis masalah dianggap sebagai metode yang tepat untuk membangkitkan dan mendorong siswa untuk meningkatkan kemampuan pemecahan masalah matematis mereka dalam kaitannya dengan materi pembelajaran tertentu.

\section{METODE PENELITIAN}

Penelitian ini dikategorikan ke dalam penelitian eksperimen semu (quasi experiment). Rancangan yang digunakan dalam penelitian ini 
meliputi tiga tahapan, yaitu: (1) Tahap pengembangan perangkat pembelajaran dan instrumen penelitian, (2) Tahap uji coba perangkat pembelajaran dan instrumen penelitian, (3) Tahap pelaksanaan eksperimen. Setiap tahapan dirancang sedemikian sehingga diperoleh data yang valid sesuai dengan karekteristik variabel sesuai dengan tujuan penelitian. Berikut rancangan setiap dalam tahapan dalam penelitian.

Penelitian yang diawali dengan pengembangan perangkat pembelajaran berupa Rencana Pembelajaran, Lembar Aktivitas Mahasiswa (LAM) yang diberikan secara online, Tes Kemampuan Pemecahan Masalah Matematika, Lembar Observasi Aktivitas Mahasiswa. Model pengembangan yang digunakan mengacu kepada model 4-D (four D-Model) yang dimodifikasi terdiri atas 4 tahap yaitu pendefinisian (define), perancangan (design), pengembangan (develop), dan penyebaran (disseminate).

\section{HASIL PENELITIAN DAN PEMBAHASAN}

Penelitian eksperimen ini dilakukan dengan prosedur yang melalui tahapan alur kerja penelitian yang diawali dengan studi pendahuluan untuk merumuskan identifikasi masalah, merumuskan masalah dan studi literatur yang pada akhirnya diperoleh perangkat penelitian berupa bahan ajar, model pembelajaran, instrumen penelitian. Perangkat penelitian ini sebelum diujicobakan telah dilakukan validasi oleh para pakar pendidikan yang berkompetensi. Selanjutnya pemilihan subyek penelitian sebagai kelas kontrol dan kelas eksperimen dengan melakukan uji beda, sebelum dilaksanakan tindakan terlebih dahulu dilakukan pretes.

Instrumen penelitian yang digunakan dalam penelitian adalah tes kemampuan pemecahan masalah, dan lembar pengamatan aktivitas mahasiswa yang dilakukan secara online. Semua data akan dianalisis untuk penarikan kesimpulan. Tes tertulis, khususnya pretest dan posttest, digunakan untuk mengumpulkan data tentang hasil kemampuan pemecahan masalah. Tes ini diberikan kepada kedua kelompok eksperimen dan kontrol. Alat ini dimaksudkan untuk menilai kemampuan pemecahan masalah siswa serta koneksi matematisnya pada materi fungsi dan konsep turunan. Jenis tes yang dibuat mengacu pada kompetensi yang akan dicapai dengan mengevaluasi acuan acuan.Menurut Kemp (1994), tes beraturan patokan ditetapkan untuk mengukur seberapa jauh setiap mahasiswa dapat mencapai kompetensi yang telah dirumuskan. Banyaknya butir soal dalam penilitian 5 butir soal. Setelah soal disusun, dilakukan telaah butir soal secara kualitatif yang bertujuan untuk menguji butir soal dari kesesuaian materi, bahasa dan konstruksi. Hal ini berkaitan erat dengan validasi isi dan format. 
Skor yang digunakan untuk menilai pemahaman siswa terhadap materi persamaan, pertidaksamaan linier satu variabel, dan perbandingan dihitung. Lingkup kapasitas kognitif adalah domain kemampuan yang diukur. Penilaian dilakukan pada timbangan geser berdasarkan berat barang. Hal ini sebagaimana dikemukakan oleh Arikunto (1996: 45), yang berpendapat bahwa ketika menggunakan skala tidak tetap untuk menentukan skor maksimum untuk tes deskripsi independen, jumlah skala tertinggi yang digunakan tidak selalu sama. Jumlah langkah dalam proses pemecahan masalah menentukan skor akhir untuk setiap item.Penelitian ini menggunakan instrumen jenis tes yaitu instrumen untuk mengukur kemampuan pemecahan masalah matematis mahasiswa. Data yang dianalisis dalam penelitian ini adalah hasil tes kemampuan pemecahan. Hasil tes memberikan informasi tentang kemampuan sebelum dan sesudah dilakukan proses pembelajaran, baik di kelas eksperimen yang maupun di kelas kontrol. Pretes dan postes kelas eksperimen diikuti oleh 40 mahasiswa dan kelas kontrol diikuti oleh 42 mahasiswa. Informasi tersebut berupa data hasil pretes dan postes. Tes kemampuan pemecahan masalah dilakukan dua kali yaitu uji awal dan uji akhir dengan soal yang ekuivalen. Peneliti mengambil sampel sebanyak masing-masing 10 orang mahasiswa dari kelas eksperimen dan kelas kontrol untuk dilakukan tes kemampuan pemecahan masalah. Tes dilakukan secara lamgsung (luring). Rata-rata skor mahasiswa terhadap materi persamaan dan pertidaksamaan linier satu variabel dan perbandingan dan kelas eksperimen dirangkum dalam Tabel berikut

Tabel 1. Rekapitulasi Ketuntasan Hasil Kemampuan Pemecahan Masalah Matematika

\begin{tabular}{c|c|l|c|c}
\hline \multirow{2}{*}{ Jenis Tes } & \multirow{2}{*}{ No } & \multicolumn{2}{|c|}{ Aspek } & \multicolumn{2}{|c}{ Kelompok } \\
\cline { 3 - 5 } & & & Kontrol & Eksperimen \\
\hline \multirow{2}{*}{$\begin{array}{c}\text { Pemecahan } \\
\text { Masalah }\end{array}$} & 1 & Proporsi skor uji awal & 1,14 & 1.11 \\
\cline { 2 - 5 } & 2 & Proporsi skor uji akhir & 6,08 & 6,94 \\
\cline { 2 - 5 } & 3 & \% Ketuntasan & 56,25 & 87,5 \\
\hline
\end{tabular}

Pada Tabel dapat dilihat, untuk kemampuan pemecahan masalah rata-rata proporsi skor uji awal dan uji akhir mahasiswa kelas kontrol adalah 1,14 dan 6,08. Bila diperhatikan rata-rata proporsi skor uji akhir terjadi peningkatan rata-rata proporsi skor sebesar 4,94.
Sedangkan kelompok eksperimen yaitu 1,11 dan 6,94 terjadi peningkatan rata-rata proporsi skor sebesar 5,83. Selisih proporsi uji awal dan uji akhir kelompok eksperimen lebih besar dari selisih proporsi skor uji awal dan uji akhir untuk kelas kontrol. Hal ini memberi petunjuk 
Glory Indira Diana Purba : Penerapan E-Learning ...

bahwa pembelajaran e-learning pemecahan masalah matematika berbasis masalah dapat meningkatkan daripada pembelajaran biasa. pada pencapaian kemampuan

Tabel 2. Deskripsi Postes Kemampuan Pemecahan Masalah Matematika Kelas Eksperimen dan Kelas Kontrol

Tests of Normality

\begin{tabular}{ll|r|r|r|r|r|r}
\hline & \multirow{2}{*}{ KELAS } & \multicolumn{2}{|c|}{ Kolmogorov-Smirnov } & \multicolumn{3}{|c}{ Shapiro-Wilk } \\
\cline { 3 - 8 } & Statistic & df & Sig. & Statistic & Df & \multicolumn{1}{c}{ Sig. } \\
\hline POST_PMASALAH & Eksperimen & .105 & 9 & .072 & .849 & 40 & .082 \\
& Kontrol & .121 & 9 & .089 & .948 & 42 & .103 \\
\hline
\end{tabular}

Dari hasil uji One Sample lebih. Pengujian homogenitas ini Kolmogorov-Smirnov tersebut, menggunakan uji varians dua buah diketahui bahwa untuk kelas peubah bebas. Untuk pengujian eksperimen nilai signifikansi adalah homogenitas dalam penelitian ini 0,072>0,05 dan untuk kelas kontrol diambil sampel di kelas kontrol $0,089>0,05$ maka postes eksperimen sebanyak 10 mahasiswa kemampuan pemecahan masalah dan kelas kontrol sebanyak 10 matematika di kedua kelas mahasiswa. Adapun hasil perhitungan berdistribusi normal. Sedangkan homogenitas pretest dan posttest untuk Uji homogenitas adalah menggunakan SPSS sebagai berikut: pengujian sama tidaknya variabelvariabel dua buah distribusi atau

Tabel 3. Hasil Uji Homogenitas Varians Pretes Pemecahan Masalah Kelas Eksperimen dan Kelas Kontrol

Test of Homogeneity of Variance

\begin{tabular}{ll|r|r|r|r}
\hline & & Levene Statistic & df1 & \multicolumn{1}{|c|}{ df2 } & \multicolumn{1}{c}{ Sig. } \\
\hline PRE_PMASALAH & Based on Mean & .458 & 1 & 18 & .501 \\
& Based on Median & .447 & 1 & 18 & .506 \\
& $\begin{array}{l}\text { Based on Median and } \\
\text { with adjusted df }\end{array}$ & .447 & 1 & 18.045 & .506 \\
& & & & & \\
& $\begin{array}{l}\text { Based on trimmed } \\
\text { mean }\end{array}$ & .515 & 1 & 18 & .476 \\
\hline
\end{tabular}


Tabel 4. Hasil Uji Homogenitas Varians Postes Pemecahan Masalah Kelas Eksperimen dan Kelas Kontrol

Test of Homogeneity of Variance

\begin{tabular}{ll|r|r|r|r}
\hline & & $\begin{array}{c}\text { Levene } \\
\text { Statistic }\end{array}$ & df1 & df2 & \multicolumn{1}{c}{ Sig. } \\
\hline POST_PMASALAH & Based on Mean & 1.452 & 1 & 18 & .233 \\
& Based on Median & .730 & 1 & 18 & .396 \\
& Based on Median and with & .730 & 1 & 18.885 & .396 \\
& adjusted df & & & \\
& Based on trimmed mean & 1.556 & 1 & .217 \\
\hline
\end{tabular}

Karena nilai signifikansi tabel. Berikut adalah hasil (mean) untuk pretest adalah 0,501 > penggunaan program SPSS untuk 0,005 dan untuk posttest adalah 0,233 menghitung tes kemandirian dan $>0,005$, maka kelas eksperimen dan koefisien kemampuan pemecahan kontrol untuk pretest dan posttest masalah matematis kelompok kemampuan pemecahan masalah eksperimen dan kontrol: memiliki varians yang sama, sesuai

Tabel 5. Analisis Varians Untuk Uji Independensi Kemampuan Pemecahan Masalah Matematika Kelas Eksperimen ANOVA ${ }^{b}$

\begin{tabular}{ll|r|r|r|r|r}
\hline Model & & Sum of Squares & Df & Mean Square & F & Sig. \\
\hline 1 & Regression & 196.420 & 1 & 196.420 & 8.794 & $.006^{\mathrm{a}}$ \\
& Residual & 670.049 & 9 & 22.335 & & \\
Total & 866.469 & 10 & & & \\
\hline
\end{tabular}

a. Predictors: (Constant), $\mathrm{X}$

b. Dependent Variable: Y

Tabel 6. Koefisien Analisis Varians Untuk Uji Independensi Kemampuan Pemecahan Masalah Kelas Eksperimen

Coefficients $^{\mathrm{a}}$

\begin{tabular}{|c|c|c|c|c|c|c|}
\hline \multirow{2}{*}{\multicolumn{2}{|c|}{ Model }} & \multicolumn{2}{|c|}{ Unstandardized Coefficients } & \multirow{2}{*}{$\begin{array}{c}\begin{array}{c}\text { Standardized } \\
\text { Coefficients }\end{array} \\
\text { Beta }\end{array}$} & \multirow[b]{2}{*}{$\mathrm{t}$} & \multirow[b]{2}{*}{ Sig. } \\
\hline & & $\mathrm{B}$ & Std. Error & & & \\
\hline \multirow[t]{2}{*}{1} & (Constant) & 29.685 & 1.892 & & 15.691 & .000 \\
\hline & $\mathrm{X}$ & .905 & .305 & .476 & 2.966 & .006 \\
\hline
\end{tabular}

F hitung sebesar 8,794 dengan taraf signifikansi 0,006 dari ANOVA atau uji $\mathrm{F}$ untuk kemampuan pemecahan masalah kelas eksperimen. Berdasarkan hasil uji linieritas dan kesejajaran model 
Glory Indira Diana Purba : Penerapan E-Learning ...

regresi dipenuhi maka untuk menguji perbedaan kemampuan pemecahan masalah matematika mahasiswa yang diajar dengan pembelajaran e learning berbasis masalah dengan kemampuan pemecahan masalah matematika mahasiswa yang diajar dengan pengajaran biasa dapat dianalisis dengan anakova sebagai modifikasi analisis varians. Untuk itu dirumuskan hipotesis analisisnya dengan menduga jarak kedua garis regresi linier kelompok kontrol dan kelompok eksperimen dari setiap skor hasil uji akhir dari rata-rata skor uji akhir kelompok kontrol dan skor uji akhir dari kelompok eksperimen. Hipotesisnya adalah sebagai berikut:

$$
\begin{aligned}
& \mathrm{H}_{0}: \theta_{4}=\theta_{2} \\
& \mathrm{H}_{a}: \theta_{4}>\theta_{2} \\
& \text { Untuk menguji hipotesis }
\end{aligned}
$$
tersebut beberapa nilai yang diperlukan dirangkum dalam tabel berikut:

Tabel 7. Analisis Kovarians untuk Rancangan Lengkap Kemampuan Pemecahan Masalah

\begin{tabular}{l|c|c|c|c}
\hline \multirow{2}{*}{$\begin{array}{l}\text { Source of } \\
\text { variation }\end{array}$} & \multicolumn{3}{c|}{ Sums of Squares or Products } & \multirow{2}{*}{ Df } \\
\cline { 2 - 4 } & $\mathbf{X}$ & $\mathbf{Y}$ & $\mathbf{X Y}$ & \\
\hline Treatments & 13814 & 10894,2 & 3566,88 & 1 \\
\hline Error & 494,97 & 1780,19 & 477,80 & 18 \\
\hline Total & 14308,97 & 12674,39 & 4044,68 & 19 \\
\hline $\begin{array}{l}\text { Source of } \\
\text { variation }\end{array}$ & Adjusted SS & \multicolumn{2}{|c|}{ Adjusted Df } & \\
\hline Treatments & 1488,89 & \multicolumn{2}{|c|}{1} & 1488,89 \\
\hline Error & 1318,97 & \multicolumn{2}{|c|}{18} & 21,62 \\
\hline Total & 2807,86 & \multicolumn{2}{|c|}{19} & \\
\hline
\end{tabular}

Dari hasil perhitungan untuk kemampuan pemecahan masalah pada Tabel diperoleh $\mathrm{F}^{*}=\frac{M S T R_{(a d j)}}{M S E_{(a d j)}}=$ $\frac{1488,89}{21,62}=68,87$ dan berdasarkan Tabel F, untuk $\alpha=5 \%$ diperoleh $\mathrm{F}$ $(0,95,1: 61)=3,995$. Berarti $F^{*} \geq F$ (0,95,1:61) sehingga $\mathrm{H}_{0}: \mathrm{r}_{1}=\mathrm{r}_{2}=0$ ditolak. Hal ini berarti ada perbedaan yang signifikan antara kemampuan pemcahan masalah mahasiswa yang dikenai perlakuan pembelajaran berbasis masalah dan mahasiswa yang dikenai pengajaran biasa. Hal ini menunjukkan bahwa terdapat perbedaan yang cukup besar, dan hipotesis yang dikemukakan di atas adalah bahwa konstanta regresi berpengaruh terhadap tinggi kedua garis regresi. Ketika $X=0$, persamaan regresi untuk kemampuan pemecahan masalah kelas pembelajaran berbasis masalah adalah $\mathrm{Y}=29,69$, sedangkan persamaan regresi untuk kelas pengajaran langsung adalah $Y=24,58$. Sehingga dapat dapat dikemukakan bahwa keterampilan pemecahan masalah siswa yang diajarkan matematika 
dapat ditingkatkan. Pada subjek

berbasis

masalah lebih disukai fungsi dan turunannya, e-learning instruksi langsung.

Tabel 8. Rangkuman Hasil Pengujian Hipotesis Penelitian Kemampuan Pemecahan Masalah Matematika pada Taraf Signifikan 5\%

\begin{tabular}{c|l|c}
\hline No & \multicolumn{1}{|c}{ Hipotesis Penelitian } & $\begin{array}{c}\text { Hasil } \\
\text { Pengujian }\end{array}$ \\
\hline 1 & $\begin{array}{l}\text { Ada pengaruh positif (signifikansi) hasil uji awal kemampuan } \\
\text { pemecahan masalah mahasiswa terhadap hasil uji akhir mahasiswa } \\
\text { untuk kelas kontrol. }\end{array}$ & Ditolak \\
\hline 2 & $\begin{array}{l}\text { Hasil uji awal kemampuan pemecahan masalah mahasiswa terhadap } \\
\text { hasil uji akhir mahasiswa untuk kelas kontrol memiliki model regresi } \\
\text { linier. }\end{array}$ & Diterima \\
\hline 3 & $\begin{array}{l}\text { Model regresi kelompok eksperimen dan model regresi kelompok } \\
\text { kontrol adalah tidak sama atau berbeda secara signifikan untuk } \\
\text { kemampuan pemecahan masalah }\end{array}$ & Ditolak \\
\hline 4 & $\begin{array}{l}\text { Model regresi kelompok eksperimen dan model regresi kelompok } \\
\text { kontrol adalah sejajar (tidak berimpit) untuk kemampuan pemecahan } \\
\text { masalah }\end{array}$ & $\begin{array}{l}\text { Diterima } \\
\text { matematika mahasiswa yang dikenai perlakuan pembelajaran berbasis } \\
\text { masalah dan mahasiswa yang dikenai pengajaran langsung }\end{array}$ \\
\hline 5
\end{tabular}

Bagian ini akan membahas bagaimana mendeskripsikan dan memahami data studi. Kemampuan pemecahan masalah matematis dijelaskan dan diinterpretasikan dalam konteks pemecahan masalah yang diberikan. Berdasarkan parameter yang termasuk dalam penelitian (kompetensi matematika siswa). Mengingat temuan penyelidikan yang disebutkan di atas, Ini menunjukkan bahwa e-learning berbasis masalah mengungguli pengajaran langsung dalam hal meningkatkan kemampuan pemecahan masalah matematis siswa. Hasil penelitian ini diperkuat temuan Suhendra (2005) dalam penelitiannya menemukan bahwa mahasiswa yang mendapatkan pembelajaran berbasis masalah dalam kelompok belajar kecil secara signifikan memiliki kemampuan pemecahan masalah matematika lebih baik dibandingkan dengan mahasiswa yang mendapatkan pembelajaran langsung.

\section{Pembahasan}

Jika diperhatikan karakteristik pembelajaran dari kedua pendekatan tersebut adalah suatu hal yang wajar terjadinya perbedaan tersebut. Secara teori, pembelajaran berbasis masalah menawarkan berbagai keunggulan dibandingkan pengajaran langsung, dan jika keunggulan ini dimanfaatkan dalam pelaksanaan pembelajaran, proses pembelajaran dapat ditingkatkan secara signifikan. Manfaat tersebut dapat dilihat melalui berbagai perspektif tentang karakteristik pembelajaran. Dalam 
penelitian ini, bahan ajar dibuat dan dikemas dalam bentuk penyajian situasi kontekstual. Siswa diberi kesempatan untuk menemukan cara meningkatkan potensi dirinya melalui suatu kegiatan, memecahkan tantangan, dan mencari tahu dengan menggunakan masalah yang disediakan. Siswa didorong untuk berperan aktif dalam mencari solusi atas tantangan. Mereka menggunakan pendekatan berpikir ilmiah yang kritis, rasional, dan sistematis untuk menganalisis peristiwa atau situasi yang mereka hadapi dan menarik kesimpulan. Kegiatan pembelajaran dilakukan dengan membahas contoh soal dan dilanjutkan dengan latihanlatihan dalam pengajaran biasa. Perangkat pembelajaran yang digunakan dalam pengajaran biasa adalah bahan ajar yang biasa digunakan oleh dosen, dan kegiatan pembelajaran dilakukan dengan membahas contoh soal dan dilanjutkan dengan latihan soal. Inilah mengapa e-learning dengan metode problem based learning lebih efektif dalam proses pembelajaran aritmatika..

\section{SIMPULAN}

Beberapa kesimpulan ditarik tentang komponen pembelajaran dan kemampuan pemecahan masalah matematis siswa berdasarkan hasil belajar, temuan, dan komentar yang disajikan pada bab sebelumnya. Berikut kesimpulannya:

- Peningkatan
pemecahan masalah matematika
mahasiswa yang memperoleh

model pembelajaran e-learning berbasis masalah lebih baik daripada kemampuan pemecahan masalah matematika mahasiswa yang memperoleh model pengajaran e-learning biasa, diperoleh rata-rata kemampuan pemecahan masalah matematika mahasiswa yang memperoleh model pembelajaran e-learning berbasis masalah adalah 6,94 sedangkan rata-rata kemampuan pemecahan masalah matematika mahasiswa yang memperoleh model pengajaran e-learning biasa adalah 6,08 .

- Aktivitas siswa dengan e-learning melalui pendekatan pembelajaran berbasis masalah adalah efektif. Dengan merujuk pada kriteria yang ditetapkan yaitu pengelolaan pembelajaran dikatakan efektif jika delapan kategori dari kriteria toleransi pencapaian keefektifan waktu yang digunakan pada sepuluh butir dipenuhi

\section{DAFTAR RUJUKAN}

Arends, I. R. 2008. Learning To Teach Belajar Untuk Mengajar Buku Satu. Yogyakarta: Pustaka Pelajar.

Arikunto, S. 2002. Dasar-Dasar Evaluasi Pendidikan. Jakarta: Bumi Aksara

Atun, I. 2006. Pembelajaran Matematika Dengan Strategi Koopretaif Tipe Student Teams Achievement Divisions Untuk 
Meningkatkan Kemampuan

Pemecahan Masalah dan

Komunikasi Siswa. Tesis tidak

diterbitkan. Bandung: Program

Pascasarjana UPI Bandung.

Barrows, S.H. 2003. Problem Based

Instruction (PBI). (Online).

(http://web.cortland.edu/frieda/I

D/IDtheories/46.html, diakses

10 Oktober 2009).

Ben-Zeev, T, \& Sternberg, R.J. 1996.

The Nature of Mathematical

Thinking. Mahwah. NJ:

Lawrence Erlbaum Associates

Inc.

Dahar, R.W. 1989. Teori-Teori

Belajar. Jakarta: Erlangga.

Depdikbud. 1995. Garis-garis Besar

Program Pengajaran (GBPP)

Mata Pelajaran Matematika.

Jakarta: Depdikbud. 